That means that doctors should consider birth year when deciding whether to offer screening, but should take other factors into account. The mediocre grade could discourage many health-care providers - including Medicaid, the provider for people with low incomes - from pushing screenings.

As with its controversial recommendations in 2009 and 2012 to limit screening for breast and prostrate cancer, the USPSTF has tried to balance the benefits of screening against the risk of unnecessary treatment. The combination therapies used to combat hepatitis $C$ can cost US $\$ 1,100$ per week and last for up to a year, with severe side effects. Other treatments cost $\$ 4,100$ per week. (Gilead declined to comment on the future price of sofosbuvirbased treatments.)

Roger Chou, an internal-medicine specialist at Oregon Health and Science University in Portland and a scientific reviewer for the USPSTF, adds that in most patients, the disease is imperceptible: only $20 \%$ of people develop liver scarring in the first 20 years of infection, according to the CDC. Of the few baby

boomers that might

be caught through

additional screening,

says Chou, some will

not need to be treated.

But new drugs,

"We have an opportunity to make a real dent in the impact of the disease."

however expensive,

could change the calculus for doctors and patients, says Mark Eckman, a physician at the University of Cincinnati in Ohio, who has calculated that even screening the entire US population would be cost effective given the financial and personal burdens of living with liver diseases (M. H. Eckman et al. Clin. Infect. Dis. 56, 1382-1393; 2013).

For example, sofosbuvir, which is one of a set of new antiviral drugs that specifically target hepatitis $C$ rather than viruses in general, can achieve success rates above $90 \%$ in combination treatments of just three months. The drug inhibits the virus's RNA polymerase, preventing viral replication. It is also being tested without the classic combination drug of pegylated interferon, which boosts the immune system but causes harsh side effects.

The USPSTF is still reviewing its draft recommendations, but it is likely to make a final decision in the next few months, well before approval of sofosbuvir or other new drugs could alter the calculations.

That is too bad, says David Thomas, a viral-hepatitis specialist at Johns Hopkins University in Baltimore, Maryland, who argues that the next generation of drugs helps to justify wide-scale screening. "It makes a pretty easy case for doing something different," he says. -

\title{
BIOMEDICINE
}

\section{Clinician to head Wellcome Trust}

\section{Jeremy Farrar to lead one of world's largest research charities.}

\section{BY RICHARD VAN NOORDEN}

$\mathrm{F}$ rom his base in Vietnam, Jeremy Farrar has spent the past 17 years on the front line of the battle with infectious diseases, from dengue and typhoid to severe acute respiratory syndrome (SARS) and now H7N9 avian influenza. The British clinician has led the Oxford University Clinical Research Unit in Ho Chi Minh City as it has grown from a dozen people to around 200 researchers supporting public-health efforts in Vietnam, Nepal and Indonesia.

Now, Farrar is stepping up to lead the UK institution that paid for much of his work: the Wellcome Trust, one of the world's largest charities funding biomedical research. Colleagues and public-health leaders say that the trust, which last year spent $£ 746$ million (US $\$ 1.15$ billion), has made an excellent choice - and wonder whether it signals an even greater focus on funding research in developing countries.

"He's massively driven, and a great visionary. He's invested his career in doing the research where the problem lies; he believes tropical medicine should be done in the tropics," says Bob Snow, one of Farrar's collaborators, who works on malaria and public health in Nairobi.

Farrar moved to Vietnam in 1996, when the Wellcome Trust was boosting investment in disease-ridden countries in Africa and southeast Asia. He saw the SARS outbreak in 2003 at close quarters - his friend, Carlo Urbani, died of the virus while working for the World Health Organization (WHO) in Hanoi. Then came a surge in $\mathrm{H} 5 \mathrm{~N} 1$ avian flu, which hit Vietnam hard. "It was a tense time for everyone," says Cameron Simmons, a dengue expert who works with Farrar; clinicians were treating patients and trying to explain the crisis. Through all of this, Farrar's leadership and ability to build trust between people was evident, says Simmons.

"Jeremy's very much a shrewd team player," says Colin Blakemore, a neuroscientist at the University of Oxford, UK, and former head of Britain's Medical Research Council. Farrar has brokered funding from several sources, and his centre's work on flu required negotiations with countries such as China to obtain samples. Those skills will serve him well when he moves to the Wellcome Trust in October.

For the past decade, Farrar has been migrating to a more strategic role, Snow says, serving on WHO advisory boards and pushing for a

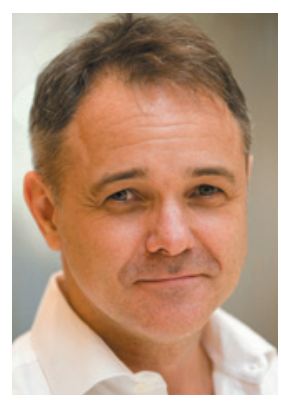

Clinician Jeremy Farrar. greater focus on flu surveillance and on capacity-building in the developing world.

"I believe that we have to bring some of the huge investment by the developed world in genomics, technology and training to affected countries in Asia and elsewhere," Farrar wrote last year (Nature 483, 534-535; 2012).

Farrar would not divulge whether his vision of international public-health strategy would affect the trust's priorities: "I have too much to do on H7N9 and hand, foot and mouth disease to talk about that," he says. But Snow says that researchers are hopeful. Since 2008, the charity - under its previous director Mark Walport, now the UK government's chief scientific adviser - has increased its spending outside the United Kingdom from 14\% to $22 \%$, expanding support for programmes in India and sub-Saharan Africa in particular. It has also doubled the share of its cash it gives to translational research, from $6 \%$ to $12 \%$. David Heymann, chairman of the advisory board for Public Health England, says that Farrar is likely to encourage those trends.

"It wasn't an easy decision for him to give up the science," says epidemiologist Simon Hay, a collaborator at the University of Oxford, "but there's a responsibility for people that have been advocating in public health to step up when these positions come up." Moreover, the Vietnam unit can now operate without Farrar.

"There will be tears from our end and from our Vietnamese partners. The trust is very lucky to be getting Jeremy — he's a remarkable leader," says Simmons.

Additional reporting by Ewen Callaway and David Cyranoski.

\section{CORRECTION}

The News Feature 'The gun fighter' (Nature 496, 412-415; 2013) did not cite the sources for the graphs. These have now been added online. 